\title{
Effects of environmental cues on metamorphosis of the blue crab Callinectes sapidus
}

\author{
Richard B. Forward Jr*, Mona C. DeVries, Dan Rittschof, David A. Z. Frankel, \\ Jennifer P. Bischoiff, Carlie M. Fisher, James M. Welch
}

Duke University, School of the Environment, Marine Laboratory, 135 Duke Marine Lab Road, Beaufort, North Carolina 28516-9721, USA

\begin{abstract}
Postlarvae (megalopae) of the blue crab Callinectes sapidus (Rathbun) are transported from shelf/coastal areas into estuares where they metamorphose (molt) to the first crab stage. This study used time to metamorphosis of megalopae collected near the entrance to estuaries as a measure of the effectiveness of cues in estuares to induce metamorphosis. Daily feeding and water change had no effect on the time to metamorphosis but the time increased as the density of larvae increased. There was a diel rhythm, in which megalopae preferentially molted during the day. Metamorphosıs was delayed in offshore water and accelerated in estuarine water The active chemical cues in estuaries were primarily $<10 \mathrm{kDa}$, and they raried in potency between estuaries. Megalopae did not preferentially metamorphose in the estuary where they were collected, which suggests that the concept of preferential recruitment to a home estuary is incorrect. Exposure to 3 species of seagrasses and the salt marsh cord grass Spartina alterniflora accelerated metamorphosis. In each case, chemical cues from the plants mimicked the response to the plants, but structural cues alone had no effect. Responses to macroalgae varied greatly with species. These results support the hypothesis of Wolcott \& DeVnes (1994; Mar Ecol Prog Ser 109:157-1531 that metamorphosis is delayed in offshore water and accelerated by cues associated with estuaries. The results suggest that the primary cues may be derived from estuarine vegetation. Acceleration of metamorphosis by cues from a variety of plants is useful if megalopae are transported to different estuaries and areas withın estuaries that have different aquatic vegetation.
\end{abstract}

KEY WORDS: Blue crab Callinectes sapidus - Megalopae $\cdot$ Metamorphosis $\cdot$ Chemical cues

\section{INTRODUCTION}

As adults, blue crabs Callinectes sapidus primarily occur in estuaries. During the life cycle, females release larvae near the entrances to estuaries. Larvae are transported offshore (Sandifer 1975, McConaugha et al. 1983) where they pass through 7 or 8 zceal stages and then molt to the postlarval or megalopa stage (Williams 1984). Megalopae are abundant near the ocean surface (Smyth 1980, McConaugha et al. 1983, Epifanio 1988, Epifanio et al. 1989) and are probably transported shoreward by wind-generated surface currents (Epifanio et al. 1984, Goodrich et al. 1989). Move-

•E-mail: rforward@mail.duke.edu ment up an estuary to the site of metamorphosis to the first crab stage is accomplished by selective tidal stream transport, in which megalopae are in the water column during rising tides at night, but absent at other times (Dittel \& Epifanio 1982, Brookins \& Epifanio 1985, Mense \& Wenner 1989, Little \& Epifanio 1991, DeVries et al. 1994, Olmi 1994). This developmental sequence suggests that megalopae do not have a home estuary to which they are preferentially recruited. However, this possibility has not been tested (Forward \& Rittschof 1994).

Wolcott \& DeVries (1994) hypothesjzed that metamorphosis is delayed in offshore water and accelerated by cues associated with estuaries. Their evidence was that the time to metamorphosis of megalopae collected offshore was reduced by $10 \%$ when 
exposed to low salinity water from an estuarine salt marsh. Recent studies supported this hypothesis. Forward et al. (1994) found that metamorphosis was accelerated by exposure to estuarine conditions such as low salinity water, estuarine water and the eelgrass Zostera marina. In addition, Brumbaugh \& McConaugha (1995) found that the presence of the green alga Ulva lactuca, which is found in estuaries, also reduced the time to metamorphosis. Collectively, these results support the suggestion that metamorphosis is stimulated by estuarine aquatic vegetation (Orth \& van Montfrans 1987, Lipcius et al. 1990, Olmi et al. 1990).

Wolcott \& DeVries (1994) also found that megalopae collected offshore were in intermolt, but that all metamorphosed within $10 \mathrm{~d}$ after collection. They suggested that something associated with the collection or holding procedures stimulated the initiation of progression toward metamorphosis. Thus, previous studies indicate that there are 2 aspects of metamorphosis that require further study. First is the effects of laboratory conditions, and second is further characterization of the specific cues in estuaries that accelerate metamorphosis.

To study these 2 aspects of metamorphosis, the present study first considered the basic biology of metamorphosis and the effects of laboratory conditions by asking several questions. First, is there a diel rhythm in metamorphosis in which molting occurs at a specific time in the light:dark cycle and does the presence of conspecifics affect metamorphosis? Second, does feeding/starvation, volume of maintenance water or daily water change affect metamorphosis?

The second series of experiments considered 4 questions concerning the specific environmental cues that accelerate metamorphosis. First, since a universal finding is that estuarine water accelerates metamorphosis, what is the size of the active molecules and do estuaries differ in the amount of these chemical cues present? Second, do megalopae preferentially molt in water from the estuary in which they were collected? Third, is metamorphosis accelerated by exposure to different seagrasses, macroalgae and salt marsh cord grass? Fourth, are the cues from plants chemical and/or structural?

\section{MATERIALS AND METHODS}

Megalopae of the blue crab Callinectes sapidus (Rathbun) were collected in plankton tows $10.67 \mathrm{~m}$ diameter net; $500 \mu \mathrm{m}$ mesh) during the season of abundant megalopae (Iate June to November 1994) about $1 \mathrm{~km}$ inside the entrance to the Newport River Estuary (Beaufort, North Carolina, USA) on rising tides at night. Megalopae were quickly transferred into offshore water (see description below) and maintained in the laboratory overnight. The next day, they were sorted according to molt stage, and only megalopae that were in intermolt (Aiken 1973, Anger 1983, Stevenson 1985) were used in experiments.

Unless otherwise stated, the general experimental procedure was to place groups of 10 megalopae in culture bowls ( $19 \mathrm{~cm}$ diameter) containing $400 \mathrm{ml}$ of the test water. Megalopae were maintained in an environmental chamber (Sherer Model CEL4-4) at temperatures and light:dark cycles similar to ambient conditions. The temperature was $25^{\circ} \mathrm{C}$ from June to September 14 , when it was decreased to $23^{\circ} \mathrm{C}$; it was lowered further to $21^{\circ} \mathrm{C}$ on October 18 . The light:dark cycle was $14: 10 \mathrm{~h}$ Erom June to October 18 and was $12: 12 \mathrm{~h}$ thereafter. With one exception, the water in the bowls was changed daily and megalopae were fed newly hatched brine shrimp nauplii (Artemia franciscana Kellogg). Glassware was scrubbed in deionized water and rinsed twice to prevent contamination between different test conditions.

Each experiment tested the effect of different treatments on time until metamorphosis (molting) of megalopae to the first crab stage. During a $24 \mathrm{~h}$ period, megalopae were monitored for molting at 3 times: at the beginning of the light phase, 7 and $14 \mathrm{~h}$ later. These times were used because the majority of molting took place during the light phase (see 'Results') and multiple sampling increased the resolution of the time to metamorphosis. For example, if during the day after an experiment began, a different megalopae metamorphosed at each of the 3 observation times, then the 3 times to metamorphosis were recorded as 1, 1.25 and $1.5 \mathrm{~d}$, respectively. Upon metamorphosis, the first crabs were removed from the bowls. Experiments continued until all megalopae had molted. Mortality during the experiments was rare and for any treatment ranged from 0 to $5 \%$.

The time to metamorphosis might vary with time of year (e.g temperature) or cohort of megalopae regardless of experimental conditions. Thus, each experiment consisted of 2 to 8 different treatments. A cohort of megalopae collected at the same time was haphazardly separated into different bowls for the different treatments. The times to metamorphosis for different treatments were then compared to determine the effects of treatment on metamorphosis. Comparisons were not made between different cohorts used for different experiments because of the potential variation between cohorts.

There were 3 general types of test water. 'Offshore water' was collected about $15 \mathrm{~km}$ seaward of the Newport River Estuary inlet. This water was beyond the estuarine plume and from an area where mega- 
lopae were collected previously in the neuston (Forward \& Rittschof 1994). It was collected at the beginning of each experiment and stored in acid washed glass carboys at room temperature throughout the experiment. The salinity of this water was about 35 ppt as measured with a refractometer (AO). 'Estuarine water' was collected daily from the Newport River Estuary. The salinity ranged from 34 to $35 \mathrm{ppt}$ throughout the experiment. 'Odor water' was pre. pared by incubating plant material for $24 \mathrm{~h}$ at a ratio of $2 \mathrm{~g}$ (wet weight) per $400 \mathrm{ml}$ of aerated offshore water. The only exception to this ratio was the experiment with the salt marsh cord grass Spartina alterniflora (15 g of cut stalks per $400 \mathrm{ml}$ of water) because the stalks had a greater weight per unit of surface area as compared to the other plants. For experiments, the plant material was removed after $24 \mathrm{~h}$ and the water was used immediately.

For chemical characterization, water from the Newport River Estuary was separated into 2 molecular size fractions by cascade pressure dialysis. The size fractions were $>10 \mathrm{kDa}$ but $<100 \mathrm{kDa}$ and $<10 \mathrm{kDa}$. Twenty liters of estuarine water was first passed through an Amicon YM 100 membrane, which separated molecules $<100 \mathrm{kDa}$ from particulates, bacteria and molecules $>100 \mathrm{kDa}$, at 40 psi $\left(2.76 \times 10^{5} \mathrm{~Pa}\right)$ nitrogen at $22^{\circ} \mathrm{C}$. Material above the $100 \mathrm{kDa}$ membrane was discarded. The $<100 \mathrm{kDa}$ water was then passed through an Amicon YM 10 membrane at 60 psi $\left(4.14 \times 10^{5} \mathrm{~Pa}\right)$ and $22^{\circ} \mathrm{C}$ until $100 \mathrm{ml}$ remained above the membrane. The filtrate ( $<10 \mathrm{kDa}$ fraction) was then used for experimentation. The retentate (material above the YM 10 membrane) contained 201 of molecules $<100 \mathrm{kDa}$ and $>10 \mathrm{kDa}$ and $100 \mathrm{ml}$ of $<10 \mathrm{kDa}$ molecules. This fluid was rinsed 3 times through the membrane with $200 \mathrm{ml}$ of sterile distilled water to reduce the amount of $<10 \mathrm{kDa}$ molecules. For tests, the $<100 \mathrm{kDa}$ but $>10 \mathrm{kDa}$ fraction was reconstituted by addition to $20 \mathrm{l}$ of offshore water.

There were 2 general series of experiments. The first determined aspects of the basic biology of metamorphosis and the effects of laboratory conditions on molting by considering: (1) the time of molting within the light:dark cycle, (2) the effects of feeding/starvation and daily water change, and (3) the effects of larval density and culture water volume. Culture water change and volume were unique to laboratory conditions, while the other factors vary in nature. The second experimental series tested for specific environmental cues that reduce the time to metamorphosis. Cues included estuarine water, species of seagrass, the salt marsh cord grass Spartina alterniflora and species of macroalgae. Since the design of the specific experiments varied, these are described in detail in the 'Results' section below.
Each experiment consisted of a number of treatments. For each treatment, there were 6 replicate bowls, each containing 10 megalopae. The mean time until metamorphosis to the first crab stage was calculated for each replicate bowl and treated as an individual variate. This procedure was used to reduce possible bowl effects. In general, the treatments were compared using a 1-way ANOVA followed by a Tukey's multiple comparison test when a significant omnibus $F$ was obtained in the ANOVA. All statistical analyses were performed with SAS software unless referenced otherwise. Data for each experiment were analyzed separately, and the dependent variable in all cases was days to metamorphosis. The data were checked for homoscedasticity ( $F_{\max }$ test; Sokal \& Rohlf 1981) and normality (Shapiro-Wilk statistic), and the presence of outliers in the data was detected using Dixon's test for outliers (Sokal \& Rohlf 1981). Any exceptions to the statistical approach are noted when the data are presented.

\section{RESULTS}

The percentage of megalopae collected in the intermolt stage was not constant throughout the season (Fig. 1). There was a slow decline from late June to the middle of October, when the percentage decreased suddenly to around $60 \%$. However, it then rebounded to above $90 \%$ in November. This variation implies that even though intermolt megalopae were used in experiments, cohorts collected on different nights may vary in the time until metamorphosis when presented with similar cues. Thus, when testing cues, only differences in the time to metamorphosis within cohorts were considered, not differences between cohorts.

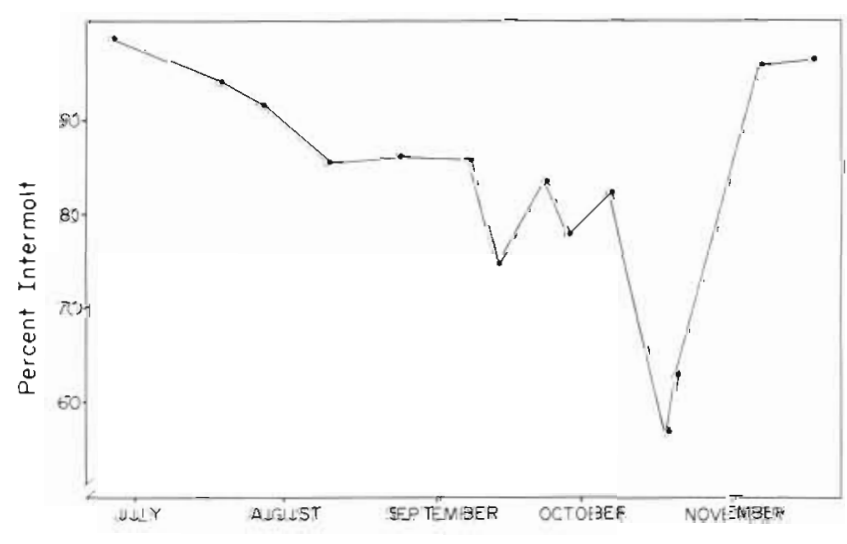

Fig. 1 Callinectes sapidus. Percentage of megalopae collected from late June to November (1994) in the Newport River Estuary that were in the intermolt stage. Average sample size at each date was 357 


\section{Laboratory conditions}

Diel rhythm in metamorphosis

To determine whether metamorphosis varied within the light:dark cycle, large numbers of megalopae were collected on one night and maintained in estuarine water at an initial density of about 50 megalopae per $400 \mathrm{ml}$ of estuarine water They were fed and their water was changed daily. They were maintained in the environmental chamber on the ambient light:dark cycle and molting was monitored at 00:00 h and 06:00 $\mathrm{h}$, and at $3 \mathrm{~h}$ intervals throughout the remainder of the day. Monitoring continued until all megalopae molted. To determine any seasonal variation, 2 trials were run in June, 1 in July and 2 in October. For data presentation, the 2 trials in June and in October were separately combined because (1) these trials were only separated in time by $1 \mathrm{wk}$, (2) the sample sizes were about the same and (3) the molting rhythms appeared to be similar. The number of megalopae that molted in each time interval was pooled over a $24 \mathrm{~h}$ day and presented as the percentage of the total number of megalopae that molted per hour.

The patterns were very similar in the different months (Fig 2). There were no single times of intense molting, such as the beginning of the dark phase. Rather, the majority of molting (>70\%) occurred throughout the day phase. Thus, in the following experiments, molting was monitored at the beginning, middle and end of the light phase. This procedure increased the resolution for determining the time of metamorphosis in the interval within the solar day when most of the molting occurred.

\section{Feeding/starvation and water change effects on} metamorphosis

Feeding/starvation and the daily water change had no effect on the time to metamorphosis (Fig. 3). Megalopal molting was monitored under 4 conditions. (1) fed brine shrimp nauplii and had estuarine water changed daily; (2) fed but not given a daily water change; (3) starved (no brine shrimp) with a daily water change; and (4) starved but not given a daily water change. There were no significant differences between treatments (2-way ANOVA). Since this experiment was performed in November at the lowest test temperature $\left(21^{\circ} \mathrm{C}\right)$, molting times were longer (Fig. 3; around $6 \mathrm{~d}$ ) than at higher temperatures. Two additional tests (not presented) of the feeding/starvation part of this experiment at higher temperatures also found no effect on molting time.

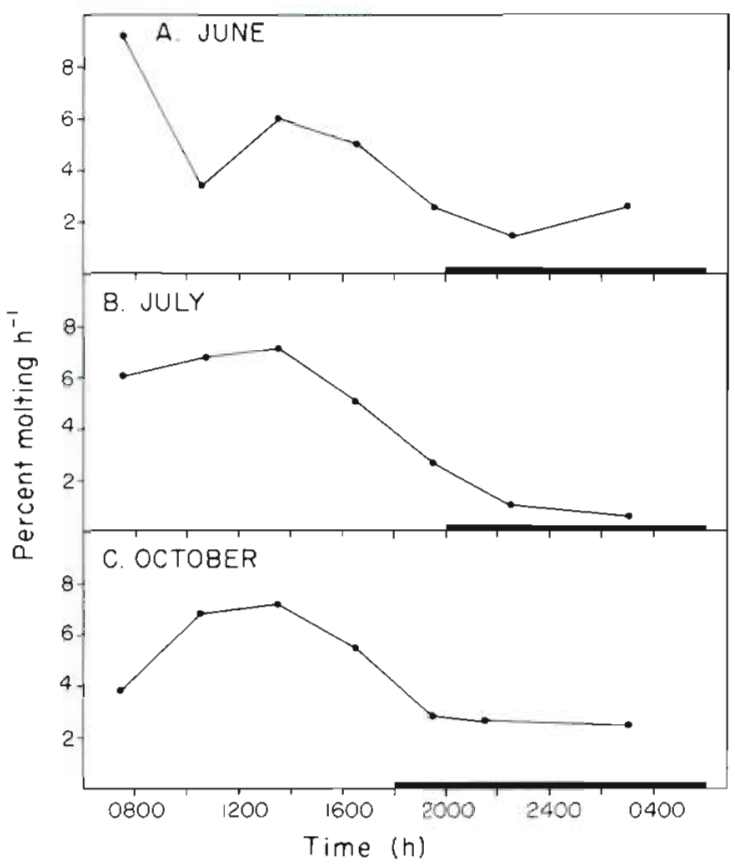

Fig. 2. Callinectes sapidus. Percentage of megalopae molting $\mathrm{h}^{-1}$ at different times within the light:dark cycle. Dark horizontal bar is the time of the night phase. Percentages were calculated by dividing the number of megalopae that had molted in each time interval by the total sample size and number of hours in the time interval. The points are plotted in the middle of each sampling interval. Total sample sizes: June, 348 ; July, 409; October, 416

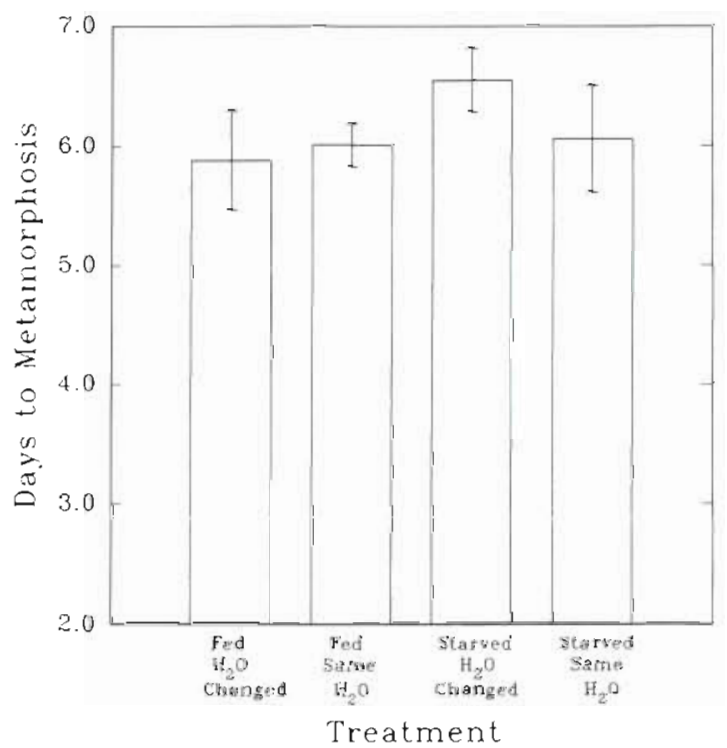

Fig. 3. Callinectes sapidus. Time to metamorphosis for megalopae maintained in Newport River Estuary water under 4 conditions: (1) fed brine shrimp nauplii with daily water change $e^{(2)}$ fed but with no daily water change; (3) starved with a daily water change; and (4) starved with no daily water change. Means and standard errors are plotted and the sample size was 6 for each treatment 
A possible explanation for the absence of a food effect was that even though food was present, the megalopae were not actually feeding on brine shrimp nauplii. This suggestion was tested by determining the diel cycle in feeding. Ten megalopae were placed individually in compartments $(5 \times 5 \times 5.5 \mathrm{~cm})$ of a plastic box. Each compartment contained $50 \mathrm{ml}$ of estuarine water and 40 nauplii. Since preliminary experiments indicated megalopae consumed $<40$ nauplii in a $24 \mathrm{~h}$ period, food was not limiting in the experiment. The box remained in the environmental chamber and at specific time intervals megalopae were transferred to new compartments with water and food. The experiment lasted $48 \mathrm{~h}$, and upon termination, the number of nauplii remaining in each compartment was counted. The number of nauplii eaten per hour for each megalopa was calculated for each time interval.

Feeding was rapid at the beginning of the experiment, but declined by about $50 \%$ after about $12 \mathrm{~h}$ and then remained relatively constant throughout the next $32 \mathrm{~h}$ (Fig. 4). There was no evidence for a diel cycle. The average feeding rate during the second day, when the rate was relatively constant, was 29 nauplii $d^{-1}$ Thus, megalopae did feed on nauplii in the experiments. In subsequent experiments, the water was changed each day, and megalopae were fed brine shrimp nauplii. These activities standardized the experimental procedure and provided a protocol, in which water containing test chemical cues was renewed each day.

\section{Effects of megalopal density on metamorphosis}

This experiment tested whether times to metamorphosis varied with number of megalopae in the rearing bowls. Water volume was held constant $(400 \mathrm{ml}$ of

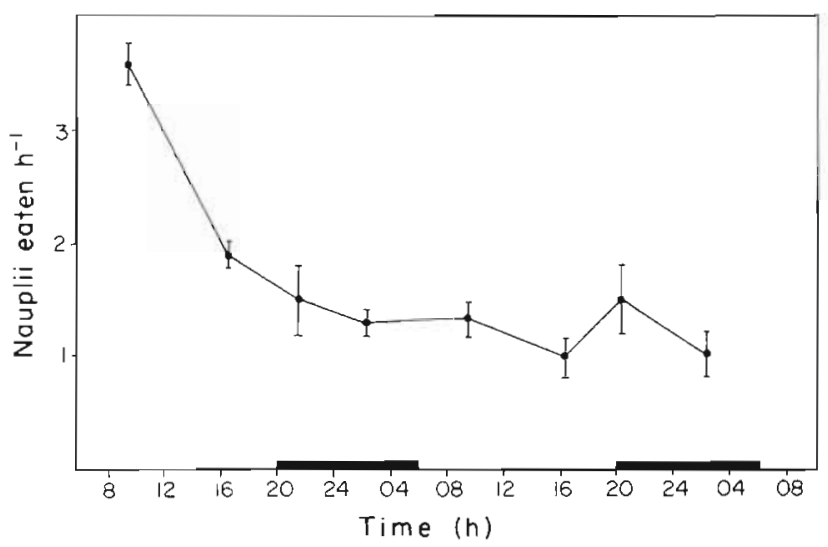

Fig. 4. Callinectes sapidus. Rate of feeding for megalopae over a $48 \mathrm{~h}$ period. Mean rates and standard errors are plotted at the middle of the measured time interval. The sample size was 10. Dark bars indicate the dark phase of the light:dark cycle estuarine water), while megallopal density varied from 1 to 40 . The time to metamoryhosis became longer as the density increased (Fig. 5. This inhibition could have resulted from increasing chemical cues from conspecifics, breakdown of esturine chemical cues by megalopae, and/or the incresse in physical interactions as megalopal density incoeased.

To test these alternatives, ratamorphosis was measured under 3 conditions: 11) 1 megalopa bowl-1; (2) 40 megalopae bowl ${ }^{-1}$; and 3) 1 megalopa in water that had previously contained 40 megalopae. The latter water was produced by incubating 40 megalopae in $400 \mathrm{ml}$ of estuarine water for $\mathrm{z} 4 \mathrm{~h}$ and then removing the 40 megalopae. New water was made each day and was assumed to contain chemical cues from the megalopae. The data were analyod with nonparametric ANOVA and nonparametric zultiple comparison by STP (Sokal \& Rohlf 1981) due so deviation of the data from normality and homoscedasticity. The times to metamorphosis for 1 megalopa with and without conspecific odor were the same and significantly shorter than that for the 40 megalopae condition (Fig. 6). These results suggest that inmibition of molting is not induced by a conspecific chem cal cue, but results from physical interactions among megalopae.

\section{Effect of water volume upon metamorphosis}

This experiment tested the suggestion of Wolcott \& DeVries (1994) that progresson toward metamorphosis is initiated by laboratory conditions. More specifi-

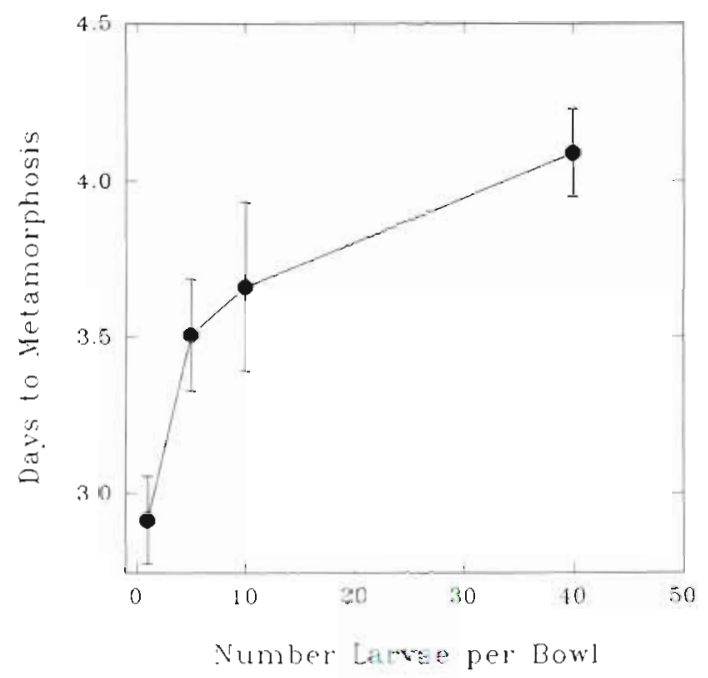

Fig. 5. Callinectes sapidus. Time to metamorphosis for megalopae at different densities in bowls with $400 \mathrm{ml}$ of water Means and standard errors are glotted and the sample size was 6 for each trestment 


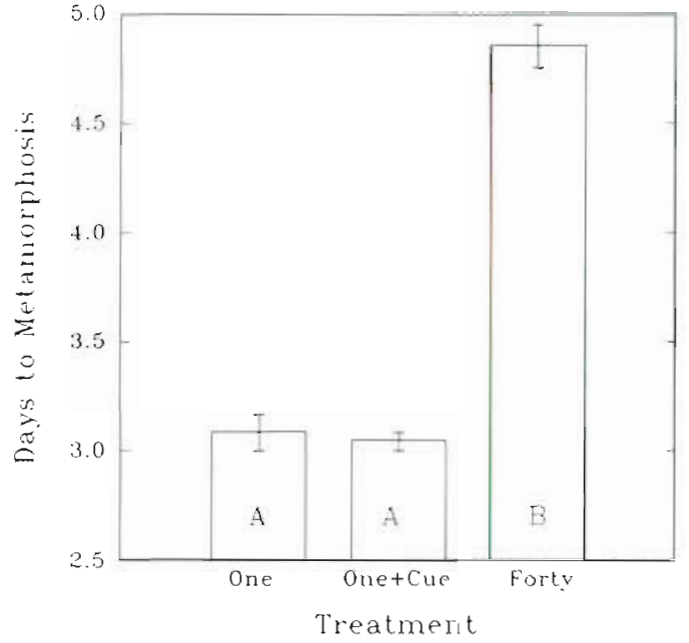

Fig. 6. Callinectes sapidus. Time to metamorphosis for megalopae in conditions of 1 and 40 megalopae bow ${ }^{-1}$ and 1 megalopa in water that had previously contained 40 megalopae (One+Cue). Means and standard errors are shown and the sample size was 6 for each treatment. Treatments with different letters were significantly different

cally, the volume of water in which megalopae are maintained may be a factor. To study this possibility, groups of 10 megalopae were tested in volumes of offshore water ranging from 200 to $3200 \mathrm{ml}$. The water was contained in glass beakers that were 20 to $25 \%$ larger than the water volume. Since all of the megalopae metamorphosed in each water volume, metamorphosis was initiated by the collection and/or laboratory procedures. The time to metamorphosis remained approximately constant as volume increased (Fig. 7). Thus, water volumes up to $3200 \mathrm{ml}$ should not affect the time to metamorphosis.

\section{Effects of environmental cues on metamorphosis}

\section{Estuarine water}

Since the previous studies indicated that chemical cues in estuarine water accelerated metamorphosis (Forward et al. 1994, Brumbaugh \& McConaugha 1995), these experiments were designed to determine the potency and size range of the active molecules. First, molting was compared simultaneously in water from 2 estuaries with megalopae from both estuaries. Second, dilution series experiments determined the potency of the chemical stimulus from the Newport River Estuary. Third, molecules in Newport River Estuary water were fractionated into 2 size classes $<<10 \mathrm{kDa}$; $>10 \mathrm{kDa}$ but $<100 \mathrm{kDa}$ and tested for effects on metamorphosis.

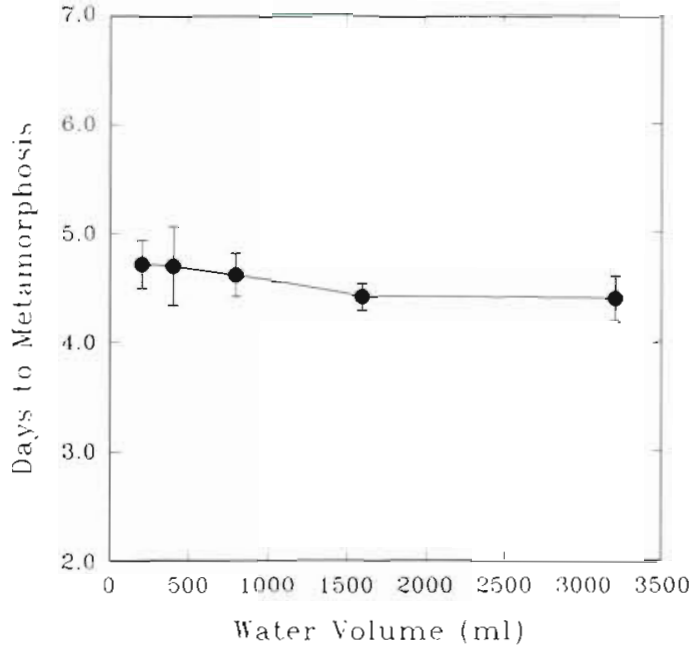

Fig. 7. Callinectes sapidus. Time of metamorphosis for megalopae in different volumes of offshore water. Mean times and standard errors are plotted and the sample size was 6 for each treatment

To compare water and megalopae from different estuaries, megalopae were collected by plankton net during rising tide on the same night from the Newport River Estuary and from the mouth of Delaware Bay. The prior exposure of these megalopae to metamorphose inducing cues was unknown, but they were collected at similar locations in 2 different estuaries on the same night. The percentages of megalopae in intermolt from the Delaware Bay and Newport River Estuary were 88 and $74 \%$, respectively. Water was also collected in the Delaware Bay at the time of megalopae collection and both water and megalopae were transported immediately to Beaufort, NC. Water was collected from within the Newport River Estuary at the same salinity (28 ppt) as water from the Delaware Bay. The location of collection of Delaware Bay water (mouth of bay) and salinity of the water indicated that it was collected within the estuarine plume. Offshore water was diluted with distilled water to $28 \mathrm{ppt}$. The experiment began about $16 \mathrm{~h}$ after collection by placing megalopae for each estuary in 3 conditions: (1) Newport River Estuary water, (2) Delaware Bay water, and (3) offshore water.

Megalopae from each estuary showed the same response pattern to the water (Fig. 8). The time to metamorphosis in Delaware Bay water was statistically the same as that in offshore water, while the time to metamorphosis in Newport River Estuary water was significantly shorter Thus, megalopae did not alter molting times in response to water from the Delaware Bay or to water from the estuary in which they were collected. The chemical cues that accelerate metamorphosis were only evident in water collected from the Newport River Estuary. 


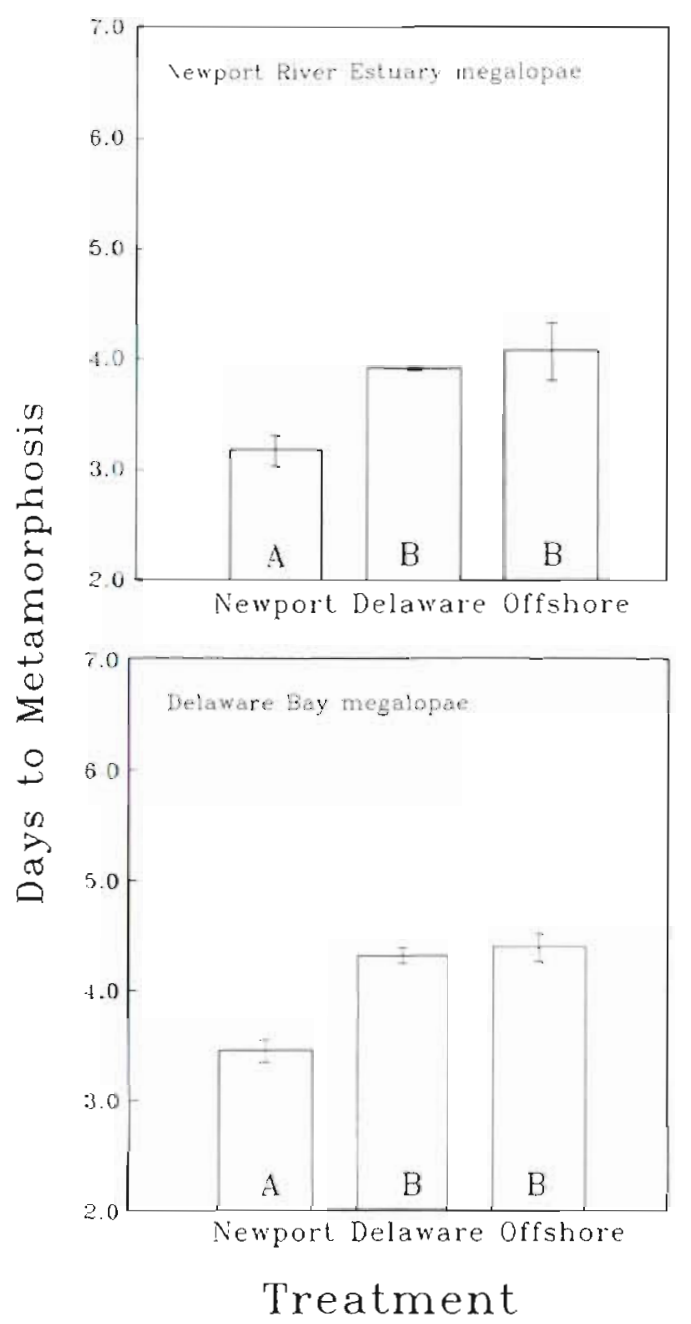

Fig. 8. Callinectes sapidus. Time to metamorphosis for megalopae collected in the Newport River Estuary and the Delaware Bay when exposed to Newport River Estuary water (Newport), Delaware Bay water (Delaware) and offshore water alone (Offshore). Means and standard errors are plotted and the sample size was 6 for each treatment. Treatments with different letters were significantly different

The potency of active molecules in Newport River Estuary water was determined by diluting estuarine water with offshore water to different percentage concentrations by volume. The lowest dilution series tested percent concentrations in the range of 0.1 to $5 \%$ (Fig 9A). There was no effect of the estuarine water concentrations, since the time to metamorphosis remained similar to that in offshore water $(0 \%)$. However, in the concentration range of 10 to $100 \%$ (Fig. 9B), all of the dilutions of estuarine water induced significantly shorter times to metamorphosis as compared to offshore water. Thus, the threshold concentration for an effect of Newport River Estuary water on metamorphosis was a concentration of between 5 and $10 \%$.
Biological activity was evident in both molecular size fractions $(<10 \mathrm{kDa} ;>10 \mathrm{kDa}$ but $<100 \mathrm{kDa})$ of Newport River Estuary water (Fig. 10). However, the larger size fraction induced molting times that were intermediate to estuarine and offshore water and not significantly different from either. An interpretation based on Fig. 9 is that less than $10 \%$ of the metamorphosis accelerating activity was in the fraction between 10 and $100 \mathrm{kDa}$. Thus, biological activity was primarily in the fraction of molecules $<10 \mathrm{kDa}$.

\section{Seagrasses}

The final 3 series of experiments tested the effects of various plants on metamorphosis. The previous study found that the presence of eelgrass Zostera marina accelerated metamorphosis (Forward et al. 1994). To determine whether this effect was due to chemical and/or structural cues from the plant, the time to metamorphosis of megalopae was measured under 6 conditions: (1) Zostera marina in offshore water; (2) offshore water that had previously contained Z. marina (odor water); (3) odor water plus artificial eel grass; (4) artificial eelgrass alone in offshore water $_{i}(5)$ clean, broken oyster shells in offshore water; and (6) offshore water alone. Artificial eelgrass con-

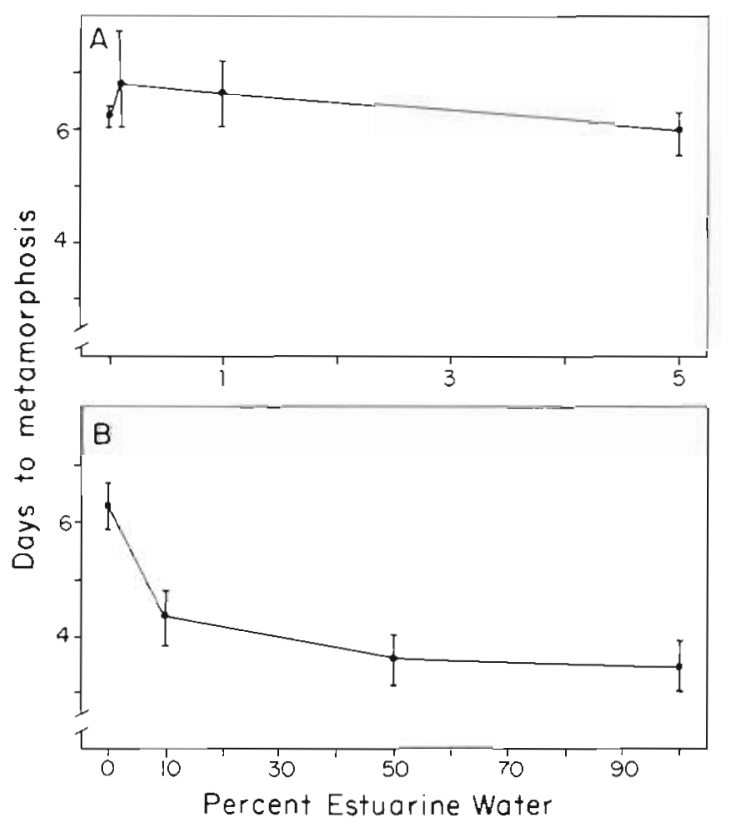

Fig. 9. Callinectes sapidus. Time to metamorphosis for megalopae in Newport River Estuary water that was diluted to concentrations of (A) 0.1 to $5 \%$ and (B) 10 to $100 \%$. Values at $0 \%$ were for offshore water. Means and standard errors are plotted and the sample size was 6 for each treatment 


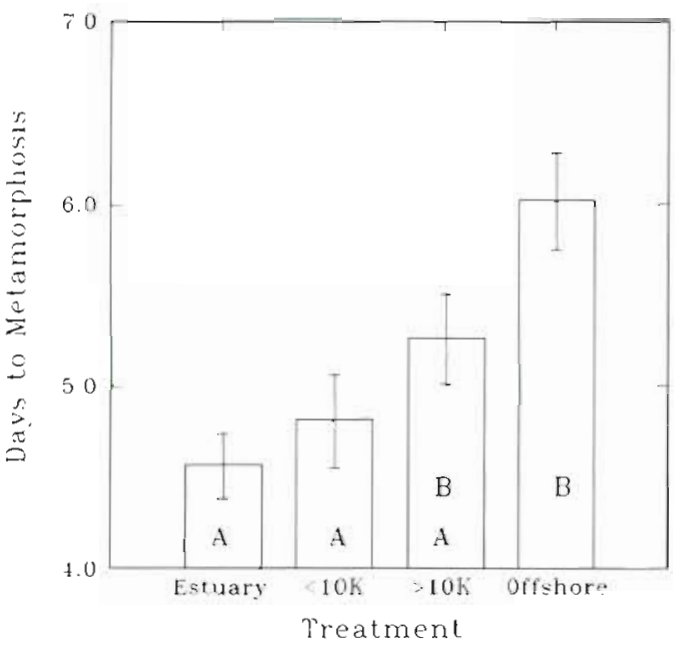

Fig. 10. Callinectes sapidus. Time to metamorphosis for megalopae in Newport River Estuary water (Estuary), estuarine water filtered to retain only molecules $<10 \mathrm{kDa}$ $(<10 \mathrm{~K})$, offshore water to which the molecules from the estuarine water that were $>10 \mathrm{kDa}$ but $<100 \mathrm{kDa}$ were added $(>10 \mathrm{~K})$ and offshore water alone (Offshore). Means and standard errors are plotted and the sample size was 6 for each treatment. Treatments with different letters were significantly different

sisted of pieces of synthetic ribbon having the same color and size of $Z$. marina. The broken oyster shells were approximately $5 \mathrm{~mm}$ in diameter, and their surface lacked obvious organic material. They covered the bottom of each finger bowl and were tested as an alternative substrate.

Since molting times were not significantly different among oyster shells, artificial eelgrass and offshore water (Fig. 11), substrate alone did not accelerate metamorphosis. In contrast, the shortest time to metamorphosis was in the presence of Zostera marina. Megalopae in odor water and odor water plus artificial eelgrass had molting times that were intermediate between $\mathcal{Z}$. marina and offshore water (Fig. 11). These results suggest that metamorphosis was accelerated by the presence of chemical cues from Z. marina

Two other species of seagrasses occur in the Newport River Estuary, Halodule wrightii and Ruppia maritima. Time to metamorphosis was tested in the presence of each of these 2 seagrass species, in water that had contained each species (odor water) and in offshore water. Molting times were not different between the 4 seagrass treatments, and all were significantly shorter than the time in offshore water (Fig. 12). Thus, the presence of these 2 seagrass species also accelerated metamorphosis, and odor from the plants was an adequate stimulus.

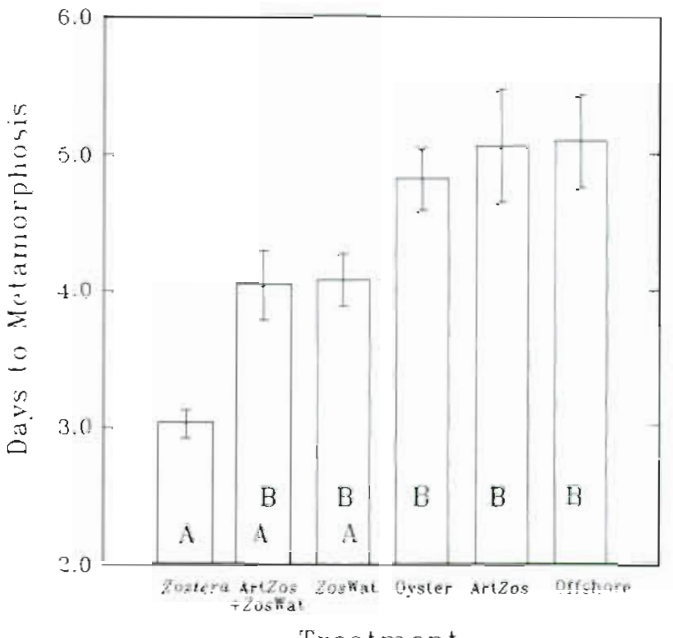

Fig. 11. Callinectes sapidus. Time to metamorphosis for megalopae in offshore water containing Zostera marina (Zostera), offshore water that had previously contained $Z$. marina plus artificial Z. marina (ArtZos + ZosWat), offshore water that had previously contained $Z$. marina for $24 \mathrm{~h}$ (ZosWat), offshore water plus oyster shells (Oyster), offshore water plus artificial Z. marina (ArtZos) and offshore water alone (Offshore). Means and standard errors are plotted and the sample size was 6 for each treatment. Treatments with different letters were significantly different

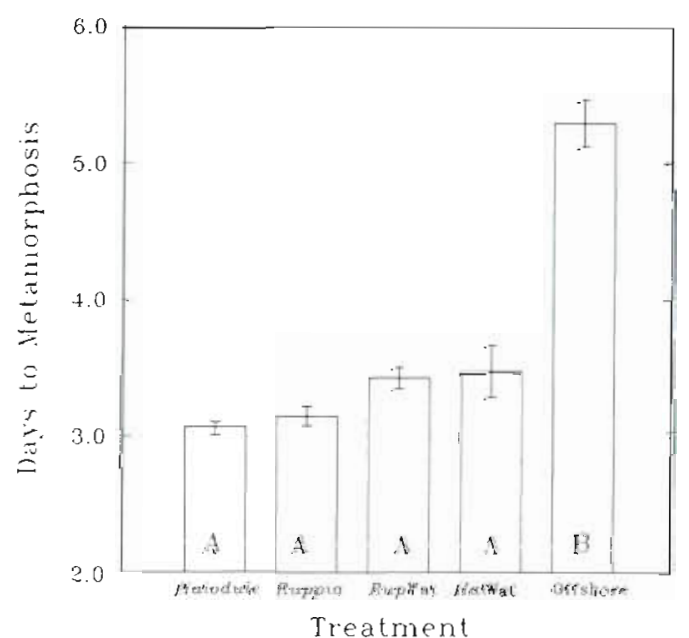

Fig. 12. Callinectes sapidus. Time to metamorphosis for megalopae in offshore water containing Halodule wrightil (Halodule) or Ruppia mantima (Ruppia), offshore water that had previously contained $R$. maritima (RupWat) or $H$. wrightii (HalWat) and offshore water alone (Offshore). Means and standard errors are plotted and the sample size was 6 for each treatment. Log-transformed data were used for statistical analyses because of the heteroscedasticity of the data. Treatments with different letters were significantly different 


\section{Salt marsh cord grass}

Perhaps the most abundant intertidal plant in the Newport River Estuary is the halophyte Spartina alterniflora (cord grass). Since preliminary experiments indicated metamorphosis was accelerated by the presence of this plant, a more detailed experiment tested whether the change in timing resulted from exposure to structural and/or chemical cues from the plant. The time to metamorphosis was tested in 6 conditions: (1) offshore water containing cut stalks of $S$. alterniflora; (2) offshore water that had previously contained cut stalks of S. alterniflora (odor water); (3) offshore water containing artificial S. alterniflora; (4) odor water plus artificial $S$. alterniflora; (5) offshore water in which the leaves of the top of $S$. alterniflora stalks were inverted into the test bowl (no cut plant edges); and (6) offshore water alone. The artificial $S$ alterniflora were plastic rods having the same length and diameter as the natural stalks.

Exposure to cut stalks of $S$. alterniflora significantly accelerated metamorphosis (Fig. 13), as compared to offshore water. Since the same effect was seen for the 2 treatments with odor water, chemical cues from the plant induced accelerated metamorphosis. Inverted $S$. alterniflora and artificial stalks produced responses that were intermediate. Thus, structure alone was

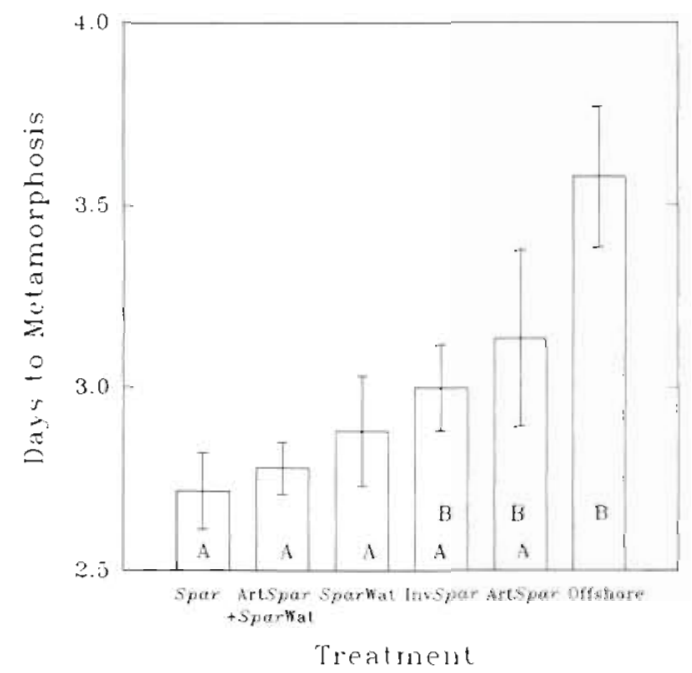

Fıg. 13. Callinectes sapidus. Time to metamorphosis for megalopae in offshore water containing Spartina alterniflora stalks (Spar), offshore water that had previously contained $S$ alterniflora to which artificial $S$. alterniflora was added (ArtSpar + SparWat), offshore water that had previously contanned S. alterniflora (SparWat), offshore water with inverted S. alternuflora (lnvSpar), offshore water that contained artificial S. altermflora (Art Spar), and offshore water alone (Offshore). Mean and standard errors are plotted and the sample size was 6 for each treatment. Treatments with different letters were significantly different inadequate to significantly accelerate metamorphosis, and leaves produced an insufficient chemical cue.

\section{Macroalgae}

When offshore in the neuston, megalopae encounter species of the brown alga Sargassum sp. floating at the surface. If Sargassum natans is added to offshore water, the time to metamorphosis $(m=7.09 \mathrm{~d}$; $\mathrm{SD}=$ $0.89 ; n=6$ ) is not significantly different from that in offshore water alone $(m=7.06 ; \mathrm{SD}=1.19 ; \mathrm{n}=6)$. A second repetition of this experiment produced the same result.

Once in an estuary, megalopae potentially encounter different macroalgae depending on time of year and location. To determine the effects of algal exposure on metamorphosis, megalopae were tested in offshore water containing either a chlorophyte (Bryopsis plumosa, Enteromorpha sp. or Ulva rotundata), phaeophyte (Scyphosipon lomentaria) or rhodophyte (Hypnea musciformis\} alga and of fshore water alone. These species were selected because they were from the 3 general groups of algae and were present during the fall months. The chlorophyte Codium fragile subsp. tomentosoides was also tested, but the data are not presented because the alga was toxic. Most of the megalopae died within $1 \mathrm{~d}$ after exposure to this alga.

Exposure to the red alga Hypnea musciformis and 2 of the green algae (Bryopsis plumosa and Ulva rotundata) significantly shortened the time to metamorphosis as compared to offshore water (Fig. 14). The other

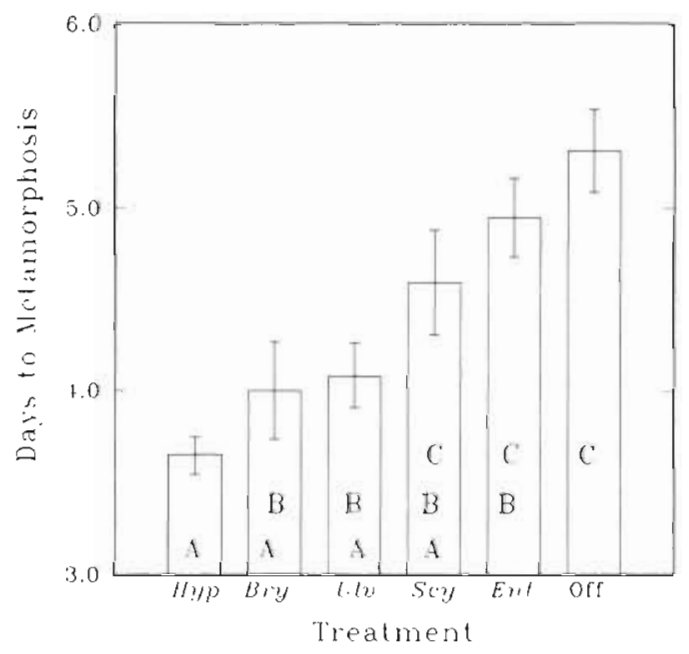

Fig. 14. Time to metamorphosis for megalopae in offshore water containing either red algae (Hypnea musciformis, Hyp) green algae (Bryopsis plumosa, Bry; Ulva rotundata, Ulv; Enteromorpha sp., Ent) or brown algae (Scyphosiphon lomentaria, Scy); or offshore water alone (Off). Means and standard errors are plotted and the sample size was 6 . Treatments with different letters were significantly different 
green alga (Enteromorpha sp.) and the brown one (Scyphosipon lomentaria) did not significantly reduce the time to metamorphosis. Thus, exposure to algae can affect metamorphosis but the effect varies with species

\section{DISCUSSION}

After molting to the megalopal stage in the continental shelf area, blue crabs are transported shoreward, probably by wind-generated surface currents, and achieve up-estuary movement by selective tidal stream transport (Dittel \& Epifanio 1982, Brookins \& Epifanio 1985, Little \& Epifanio 1991, DeVries et al. 1994, Olmi 1994). While in offshore areas, they are in intermolt (Wolcott \& DeVries 1994), and upon exposure to an unknown cue(s), progression toward premolt and eventual metamorphosis are initiated. Megalopae tested in the present study were in the latter state because, regardless of experimental treatment, almost all megalopae eventually metamorphosed. The results from the present study indicated that once collected in an estuary, metamorphosis was regulated by the light:dark cycle and was accelerated or delayed by specific cues. Acceleration was induced by chemical cues while delay occurred in response to increased megalopal density and exposure to offshore water.

Megalopae had a clear rhythm in which the greatest percentage of metamorphosis occurred during the day phase of the light:dark cycle. This pattern agrees with transport in the estuary because megalopae actively swim in the water column during flood tides at night, but are rarely collected at any time during the day (e.g. DeVries et al. 1994). This pattern results from light inhibition of swimming during the day (Forward \& Rittschof 1994) and an ascent in the water column in response to the salinity increase during rising tide at night (Tankersley et al. 1995). Thus, during the day megalopae do not actively swim in the water column and are on or near the bottom. Since swimming is difficult during molting, metamorphosis occurs at a time and location at which swimming is reduced.

Megalopae actively fed on brine shrimp nauplii in the laboratory, but there was no diel rhythm in feeding. These results differ from those with megalopae of the crab Rhithropanopeus harrisii, which consumed more nauplii during the day than at night (Cronin \& Forward 1980). Even though blue crab megalopae fed in the presence of food, the time to metamorphosis of megalopae collected near the mouth of an estuary was not altered by feeding or starvation. The effect of feeding on crustacean development rate may be speciesspecific (McConaugha 1985) because laboratory studies demonstrated that reduced food lengthened the larval developmental time (Welch \& Sulkin 1974, Welch \& Epifanio 1995) or had no effect (Brick 1974). Nevertheless, the results indicate that blue crab megalopae enter an estuary with sufficient energy reserves to metamorphose to the first crab stage without additional feeding. Also, since changing the culture water did not affect metamorphosis, any build-up of metabolites did not affect this process.

Gregarious settlement among marine invertebrates indicates that cues from conspecifics can induce metamorphosis (Crisp 1984, Rittschof 1985, Christy 1989, Jensen 1989, O'Connor 1991). Nevertheless, the barnacle Balanus amphitrite settles gregariously, but crowding during the last larval stage (cyprid) delays metamorphosis (Pechenik et al. 1993). The same pattern was observed for blue crabs, in which an increase in megalopal density lengthened the time to metamorphosis. Since water presumably containing chemical cues from conspecifics was not inhibitory, the physical presence of other megalopae induced this response. A possible implication of this result is that blue crab megalopae would be inhibited from undergoing metamorphosis if they settled in areas having large numbers of megalopae and would continue transport up the estuary to areas of low density. A further implication of these results is that the absolute times to metamorphosis in the present experiments were unique to the test density of 10 megalopae per $400 \mathrm{ml}$ of water and would have varied if another density was used.

Wolcott \& DeVries (1994) noted that megalopae collected offshore were all in intermolt, which was interpreted as a delay in progression to metamorphosis However, once placed in laboratory conditions, all megalopae metamorphosed within $10 \mathrm{~d}$. Wolcott \& DeVries (1994) suggested that laboratory conditions stimulated megalopae to initiate events leading to metamorphosis. One of the most dramatic changes from the normal planktonic existence is the confinement in a small volume of water in a finger bowl in the laboratory. The present study tested whether water volume affected metamorphosis. Offshore water was used in this experiment because Wolcott \& De Vries' (1994) study suggested metamorphosis was delayed by megalopae in offshore areas. Since all of the test megalopae metamorphosed, they had received the cue(s) for initiating progression toward metamorphosis. Thus, only the influence of water volume on the time to metamorphosis was actually tested in the experiment. Time to metamorphosis did not vary with water volumes ranging from 200 to $3200 \mathrm{ml}$ This result indicates either that water volume was not important, or that the largest test volume was still too different from the natural environment to affect time to metamorphosis. 
Both Forward et al. (1994) and Brumbaugh \& McConaugha (1995) found that time to metamorphosis significantly decreased when blue crab megalopae were exposed to estuarine water as compared to times in offshore water The present study found that potency varied between estuaries and cues were associated with many types of estuarine vegetation. Newport River Estuary water contained cues for accelerating metamorphosis. In the case of Delaware Bay water, it was clearly estuarine because of its salinity, but it did not accelerate metamorphosis. This finding indicates that cues from estuarine vegetation were below threshold concentration in the Delaware Bay water Thus, progress toward metamorphosis could begin at different distances seaward of different estuaries depending upon the concentration of the active material in the estuary and dilution.

Since metamorphosis-accelerating factors were present in both molecular size fractions of Newport River Estuary water, the chemical cues are a heterogeneous mixture of different size classes of molecules. Their association with both vascular plants (seagrasses and cord grass) and macroalgae is consistent with suggestions that the cues are degradation products of plant structural elements or exopolymers from bacteria associated with plants (Rittschof 1993). There is evidence that at least Spartina alterniflora generates odors, since the snail Littoria irrorata is attracted to water-borne cues associated with this salt marsh plant (Duval et al. 1994). Future studies should focus on the actual mechanisms of cue generation and the nature of the active chemicals.

Forward \& Rittschof (1994) suggested that blue crab larvae may become imprinted on odor from a home estuary during embryological development. Since water from different estuaries differs in chemical composition, as indicated above, then behavior appropriate for up-estuary transport could be evoked by water from the home estuary. Thus, megalopae would have the greatest likelihood of returning to the parent habitat. A logical extension of this suggestion is that metamorphosis should preferentially occur in the home estuary, where larvae are undergoing up-estuary transport.

The present study tested this suggestion by measuring the time to metamorphosis for megalopae collected in the Newport River Estuary and Delaware Bay in water for each estuary. Since the 2 estuaries are geographically separated, they do not have the same drainage basins or flora. Both groups of megalopae had accelerated metamorphosis in the Newport River Estuary water as compared to times in the Delaware Bay water. Thus, megalopae did not preferentially molt in water from the estuary in which they were collected. This result indicates that the concept of a home estuary is incorrect.
The effect of vegetation on metamorphosis was tested by adding plant cues to offshore water and determining whether the time to metamorphosis was decreased as compared to the time in offshore water. Since chemical cues that accelerate metamorphosis are present in estuarine water, adding plants to estuarine water only slightly decreases the time to molting (Forward et al. 1994). Thus, any effects of plant cues on metamorphosis are most evident if they are added to offshore water

Distribution studies demonstrated that beds of submerged vegetation are important nursery areas for blue crabs (Heck \& Orth 1980, Heck \& Thomas 1984). More specifically, megalopae preferentially settle in seagrass beds (Orth \& van Montfrans 1987, Olmi et al. 1990), which appear to be suitable areas for survival and growth (van Montfrans et al. 1990, Wilson et al. 1990). The present study tested the 3 species of seagrass that occur in the Newport River Estuary.

Exposure to all 3 species of seagrasses accelerated metamorphosis, which agrees with results from the previous study using Zostera marina (Forward et al. 1994). For each seagrass species, the effect was mimicked by exposure to water that had previously contained the seagrass. Thus, megalopae shortened the time to metamorphosis in response to chemical cues. Structure alone in the form of artificial seagrass or oyster shells had no effect on metamorphosis. When structure was combined with chemical cues, the effect was no different than that with chemical cues alone, which again indicates that the primary cues from seagrasses were chemical.

Even though the foregoing results indicate blue crab megalopae will preferentially metamorphose in or near seagrass beds, metamorphosis in areas lacking seagrass may occur in the vicinity of other aquatic vegetation. A widespread aquatic plant in the Newport River Estuary is the salt marsh cord grass Spartina alterniflora. Exposure to cut stalks significantly shortened the time to metamorphosis. Since water that previously contained cut stalks had a similar effect, but artificial stalks did not, accelerated metamorphosis was a response to chemical cues. Wolcott \& DeVries (1994) also found that the time to metamorphosis decreased upon exposure to water that had covered blocks of salt marsh from the Newport River Estuary. This response to $S$. alterniflora suggests that salt marshes may also serve as a nursery area for blue crabs. The absence of a response to oyster shells indicates that unvegetated bottom covered with scoured shells is not a likely site for metamorphosis. However, oyster shell may still be important, since shells coated with mud and vegetation also need to be tested as sites for metamorphosis. 
In offshore areas, megalopae occur in the neuston where they encounter species of the brown alga Sargassum floating at the surface. Exposure to $S$. natans did not accelerate metamorphosis. This response may be expected because Sargassum spp. represents offshore, not estuarine, areas, and members of the community of animals associated with this alga feed on zooplankton (Teal \& Teal 1975). Thus, metamorphosis in the vicinity of Sargassum spp. lacks apparent functional significance

In some estuaries, benthic macroalgae are the predominant submerged vegetation (Brumbaugh \& McConaugha 1995). In the present study, 1 red (Hypnea musciformis) and 2 green (Bryopsis plumosa and Ulva rotundata) algae accelerated metamorphosis, but there were no effects upon exposure to another green (Enteromorpha sp.) and a brown (Scyphosiphon lomentaria) alga. This variation with species agrees with results of Brumbaugh \& McConaugha (1995), who found that exposure to $U$. lactuca reduced the time to metamorphosis, but there was no effect of Gracilaria spp.

The present study supports the hypothesis of Wolcott \& DeVries (1994) that the time to metamorphosis of blue crabs is delayed in offshore water and accelerated by cues associated with estuaries. Since megalopae in the present study were captured near the mouth of estuaries, they had been exposed to estuarine conditions prior to experimentation and were probably cued to initiate premolt. The actual time to metamorphosis, however, was then delayed by exposure to offshore water and accelerated by exposure to estuarine water.

In conclusion, the active chemical cues in estuarine water mainly consist of molecules that are $<10 \mathrm{kDa}$. There was no evidence for return to, and molting in, a home estuary. The chemical cues in estuaries are probably derived from plants or bacteria associated with plants. Exposure to various estuarine plants (seagrasses, Spartina alterniflora, and various macroalgae) accelerated metamorphosis, and in every case tested, chemical cues from the plants mimicked the effects of exposure to the plant. Activation of metamorphosis by cues from a variety of plants is useful if megalopae are transported to different estuaries and areas within estuaries that have different aquatic vegetation.

Acknowledgements. This matenal is based on research supported by the National Science Foundation (OCE-9114960) and a Pew Fellowship to D.Z.F

\section{LITERATURE CITED}

Aiken DE (1973) Proecdysis, setal development, and molt prediction in the American lobster (Homarus americanus). J Fish Res Bd Can 30:1337-1344

Anger K (1983) Moult cycle and metamorphosis in Hyas araneus larvae (Decapoda, Majidae), reared in the lishoratory. Helogländer Meeresunters 36-285-302
Brick RW (1974) Effects of water quality, antibiotics, phytoplankton and food on survival and development of larvae of Scylla serrata (Crustacea: Portunidae). Aquaculture 3 $231-244$

Brookins KG, Epifanio CE (1985) Abundance of brachyuran larvae in a small coastal inlet over 6 consecutive tidal cycles. Estuaries 8:60-67

Brumbaugh RD, McConaugha JR (1995) Time to metamorphosis of blue crab Callinectes sapidus megalopae: effects of benthic marcoalgae. Mar Ecol Prog Ser 129:113-118

Christy. JH (1989) Rapid development of megalopae of the fiddler crab Uca pugilator reared over sediment: implications for models of larval recruitment. Mar Ecol Prog Ser 57: $259-265$

Crisp DJ (1984) Overview of research on marine invertebrate larvae 1940-1980. In: Costlow JD, Tipper RC (eds) Marine biodeterioration. Naval Institute Press, Annapolis, MD, p 103-126

Cronin TW, Forward RB Jr (1980) The effects of starvation on phototaxis and swimming. Biol Bull 158:283-294

DeVries MC, Tankersley RA, Forward RB Jr, Kirby-Smith WW, Luettich RA (1994) Abundances of crab megalopae are associated with estuarine tidal hydrologic variables. Mar Biol 118:403-413

Dittel AI, Epifanio CE (1982) Seasonal abundance and vertical distribution of crab larvae in Delaware Bay, USA. Estuaries 5:197-202

Duval MA, Calzetta AM, Rittschof D (1994) Behavioral responses of Littorina irrorata (Say) to water-borne odors. J chem Ecol 20:3321-3334.

Epifanio CE (1988) Transport of invertebrate larvae between estuaries and the continental shelf. Am Fish Soc Symp 3: $104-114$

Epifanio CE, Masse AK, Gravine RW (1989) Transport of blue crab larvae by surface currents off Delaware Bay, USA. Mar Ecol Prog Ser 54:35-41

Epifanio CE, Valenti CC, Pembroke AE (1984) Dispersal and recruitment of blue crab larvae in the Delaware Bay, USA. Estuar coast Shelf Sci 18:1-12

Forward RB Jr, Frankel DAZ, Rittschof D (1994) Molting of megalopae from the blue crab Callinectes sapidus: effects of offshore and estuarine cues. Mar Ecol Prog Ser 113: $55-59$

Forward RB Jr, Rittschof D (1994) Photoresponses of crab megalopae in offshore and estuarine waters: implications for transport. $J$ exp mar Biol Ecol 182:183-192

Goodrich DM, van Montfrans J, Orth RJ (1989) Blue crab megalopal influx to the Chesapeake Bay: evidence for a wind-driven mechanism. Estuar coast Shelf Sci 29: $247-260$

Heck KL Jr, Orth RJ (1980) Seagrass habitats: the roles of habitat complexity, competition and predation in structuring associated fish and motile macronnertebrate assemblages. In: Kennedy VS (ed) Estuarine perspectives. Academic Press, New York, p 449-464

Heck KL Jr, Thomas TA (1984) The nursery role of seagrass meadows in the upper and lower reaches of the Chesapeake Bay. Estuaries 7:70-92

Jensen GC (1989) Gregarious settlement of megalopae of the porcelain crab Petrolisthes canctipes (Randall) and P. eriomerus Stimpson. J exp mar Biol Ecol 131:223-231

Lipcius RN, Olmi EJ III, van Montfrans J (1990) Planktonic availability, molt stage and settlement of blue crab postlarvae. Mar Ecol Prog Ser 68:235-242

Little KT, Epifanio CE (1991) Mechanism for the reinvasion of the estuary by two species of brachyuran megalopae. Mar Ecol Prog Ser 68:235-242 
McConaugha JR (1985) Nutrition and larval growth. In: Wenner A M (ed) Crustacean issues 2: larval growth. AA Balkema, Rotterdam, p 127-159

McConaugha JR, Johnson DF, Provenzano AJ, Maris RC (1983) Seasonal distribution of larvae of Callinectes sapidus (Crustacea: Decapoda) in the waters adjacent to Chesapeake Bay. J crust Biol 3:582-591

Mense DJ, Wenner EL (1989) Distribution and abundance of early life history stages of the blue crab Callinectes sapidus in tidal marsh creeks near Charleston, South Carolina. Estuaries 12:157-168

O'Connor NJ (1991) Flexibulity in timing of the metamorphic molt by fiddler crab megalopae Uca pugilator. Mar Ecol Prog Ser 68:243-247

Olmi EJ III (1994) Vertical migration of blue crab Callinectes sapidus megalopae: implications for transport in estuaries. Mar Ecol Prog Ser 113:39-54

Olmi EJ III, van Montfrans J, Lipcius RN, Orth RJ, Sadler PW (1990) Variation in planktonic availability and settlement of blue crab megalopae in the York River, Virginia. Bull mar Sci 46:230-243

Orth RJ, van Montfrans $\mathrm{J}$ (1987) Utilization of a seagrass meadow and tidal marsh creek by blue crabs Callinectes sapidus. I. Seasonal and annual variations in abundance with emphasis on post-settlement juveniles. Mar Ecol Prog Ser 41:283-294

Pechenik JA, Rittschof D, Schmidt AR (1993) Influence of delayed metamorphosis on survival and growth of juvenile barnacles Balanus amphitrite. Mar Biol 115:287-294

Rittschof D (1985) Oyster drills and the frontiers of chemical ecology: unsettling ideas. A.m. malacol Bull (Spec Edn) 1: 111-116

Rittschof D (1993) Body odors and neutral-basic peptides mimics: a review of responses of marine organisms. Am Zool 33:487-493.

Sandifer PA (1975) The role of pelagic larvae in recruitment to populations of adult decapod crustaceans in York River Estuary and adjacent lower Chesapeake Bay, Virginia. Estuar coast mar Sci 3:269-279

This article was submitted to the editor
Smyth PO (1980) Callnnectes (Decapoda: Portunidae) larvae in the Middle Atlantic Bight, 1975-1977. Fish Bull US 78: $251-265$

Sokal RR, Rohlf FJ (1981) Biometry, 2nd edn. WH Freeman and Co, New York

Stevenson JR (1985) Dynamics of the integument. In: Bliss DE (ed) The biology of crustacea, Vol. 9. Integument, pigments, and hormonal processes. Academic Press, New York, p 1-42

Tankersley RA, Mckelvey LM, Forward RB Jr (1995) Responses of estuarine crab megalopae to pressure, salintty and light: implications for flood-tide transport. Mar Biol 122:391-400

Teal J, Teal M (1975) The Sargasso Sea. Little, Brown and Co, Boston

van Montfrans J, Peery CA, Orth RJ (1990) Daily, monthly and annual settlement patterns by Callinectes sapidus and Neopanope sayi megalopae on artificial collectors deployed in the York River, Virginia: 1985-1988. Bull mar Sci 46:214-229

Welch JM, Epifanio CE (1995) Effect of variation in prey abundance on growth and development of crab larvae reared in the laboratory and in large field-deployed enclosures. Mar Ecol Prog Ser 116:55-64

Welch J, Sulkin S (1974) Effect of diet concentration on mortality and rate of development of zoeae of the xanthid crab Rhithropanopeus harrisii (Gould). J. Elisha Mitchell scient Soc $90: 69-72$

Williams $A B$ (1984) Shrimps, lobsters, and crabs of the Atlantic coast of the Eastern United States, Maine to Florida. Smithsonian Inst. Press, Washington, DC

Wilson K, Able K, Heck K Jr (1990) Predation rates on juvenile blue crabs in estuary nursery habitats: evidence for the importance of macroalgae (Ulva lactuca) Mar Ecol Prog Ser 58:243-251

Wolcott DL, DeVries MC (1994) Offshore megalopae of Callinectes sapidus: depth of collection, molt stage and response to estuarine cues. Mar Ecol Prog Ser 109: $157-163$

Manuscript first received: April 10, 1995

Revised version accepted: July 17, 1995 